\title{
5
}

\section{WOMEN'S ACCESS TO SCIENCE PROGRAMMES IN HIGHER EDUCATION IN AFRICA}

\author{
JoelB. Babalola
}

\begin{abstract}
This paper seeks to prefer solutions to the problems of limited access of African women to higher education in the area of science and technology. As a matter of fact, African women not only suffer from limited access to higher education, but due to supply and demand factors, are also prevented from pursuing those courses like their male counterparts at that level.
\end{abstract}

In analyzing the effect of the supportive or limiting factors on women's access to science and technology courses, the author is of the opinion that for African countries to attain a very high profile in science and technology, they have to mobilize the genius of their womenfolk, sharpen their policy measures and seek the support and cooperation of the international agencies.

Furthermore, African countries should consider the formation of country and gender - specific programmes as important ingredients to the successful implementation of women access to science in the higher education scheme.

And finally, though Africa has several alternatives to encourage women's greater participation in science and technology courses in higher institutions, expansion policies which are complemented with cost-reducing and benefit-raising strategies are favoured. 
Women's access to service programmes in higher education in Africa 69

\section{INTRODUCTION}

Limited access to higher education is a common feature in developing countries. As at 1970, for instance, when countries in the developed part of the world had 24 per cent higher education enrolment rate, higher education systems in developing countries continued to enroll less than 5 per cent of the 20 - 24 age population (Knowles, 1977). By 1990, developed countries had about 38 per cent third level enrolment rate, while developing countries had 16.4 per cent (Table 1). As of that time, sub-Saharan Africa enrolled in schools just 10 per cent of the 18 - 23 age population. In fact, Africa (excluding Arab countries) had the least higher education enrolment ratio among other continents of the world.

However, owing to the importance attached to skilled manpower production, Africa experienced a remarkable rate of growth in higher education enrolment in the 1980 s, during which the annual average rate of growth in student number was 6.9 per cent for Africa as a whole, and 8.1 per cent for sub-Saharan Africa in particular. According to UNESCO (1991: 18), "this was one of the highest rates in the world" While the general expansion of the higher education system has led to greater participation for both boys and girls, it has not been able to redress the gender gap (at present in favour of men) in higher education enrolment rates. Table 1 shows that between 1975 and 1988, Africa (excluding Arab States) experienced the highest rate of growth in female enrolment (267 per cent). Yet in 1988, it recorded the least female participation in higher education in the world, that is, 19 per cent of total women enrolment While at the primary level no particular gender gap can be observed in enrolment levels, the percentage of female enrolment tends to decline at the secondary level and become lower still at the tertiary level And what is more, female participation in some science and technology subjects is insignificant (UNESCO, 1992:326). Considering the huge efforts being made in Africa to encourage women education, the question is: what is actually responsible for the extremely low female participation in higher education in the continent? The next section of this paper will address this question.

\section{WOMEN'S INTEREST IN SCIENCE AT THE HIGHER EDUCATION LEVEL}

In the poorest and least developed regions of the world of which Africa is one, gender gap is made manifest in lower enrolment rates, higher wastage rates and fewer levels of attainment for girls. According to Hyde (1991: 81), inequality is also apparent in the differences in curriculum choices offered to or made by men and women at the secondary and tertiary levels, most notably in the low science and technology enrolment figures for women.

Although the "mass movements" in higher education in Japan, America, Canada and the former Soviet union are yet to be experienced in most African 
countries, these countries are mandated, owing to equity factor, to ensure that access opportunities between boys and girls are equal (UNESCO, 1991). Nevertheless, it is expected that Africa should, at least, reach up to half of Canada's level of performance as far as the percentage of women in total enrolment by field of study in higher institutions is concerned.

Table 2 shows that despite the general low female enrolment in most of the fields of study in Africa's higher institutions, Canada did not perform better than Africa in Transport, Communication and, Engineering. However, Africa did not achieve half of Canada's level of performance in Natural Sciences, Social Sciences, Humanities, Agriculture, Medical Science, Trades and Education Science.

Looking at the pattern of female enrolments in Africa and Canada, it is glaring that there is a natural and universal dichotomy between men and women with regard to interests in some courses. For example, while there was a relatively high female participation in Home Economics/Domestic Science, Fine and Applied Arts, Humanities, Religion and Theology, there was a general low participation of women in Agriculture, Town Planning, Transport and Engineering. This points to the fact that the problem of differential interests of men and women in some fields of study in higher institutions is important to explain the issue of second-class status of women within the educational system not only in Africa, but universally.

Table 1:

Percentage Female Enrolment, Index Number of Female Enrolment and Estimated Enrolment Ratios at the 3rd Level of Education

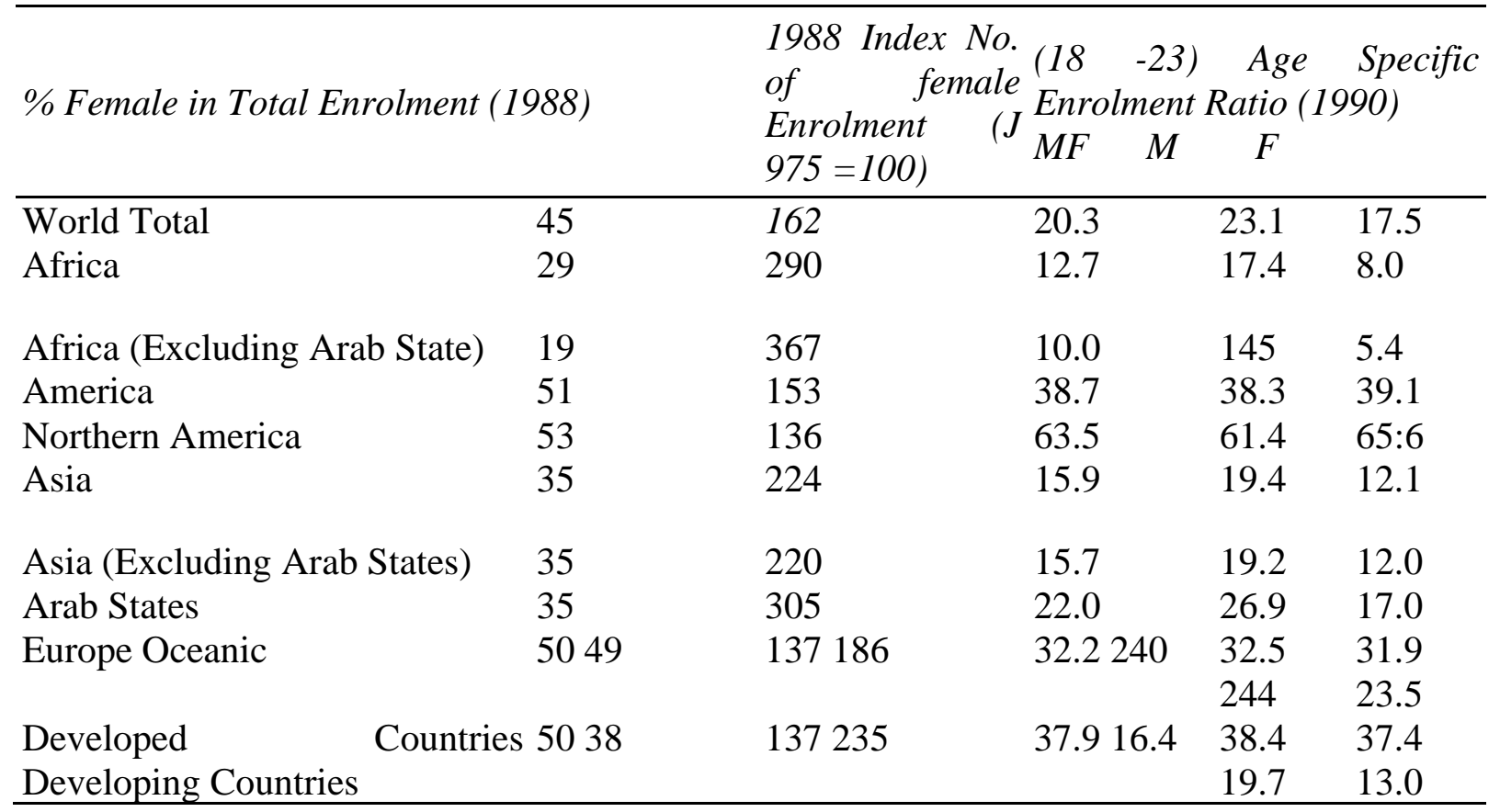

Source: UNESCO, Statistical Year Book, 1990 
Women's access to service programmes in higher education in Africa 71

Table 2:

Percentage of Women Total Enrolment by Field of Study in Africa and Canada by 1988

\begin{tabular}{|c|c|c|c|c|c|}
\hline \multirow[t]{2}{*}{ Field of Study } & \multirow{2}{*}{\multicolumn{2}{|c|}{$\frac{\% \text { Female }}{\text { Africa }}$}} & \multicolumn{3}{|c|}{ Africa's performance as a } \\
\hline & & & $\mathrm{Cal}$ & & percentage of Canada's \\
\hline Transport and Communication & 15 & (14) & 11 & (15) & 136.36 \\
\hline Engineering & 11 & (16) & 11 & (15) & 100.0 \\
\hline Home Economics/ & & & & & \\
\hline Domestic Science & 71 & (1) & 91 & (1) & 78.02 \\
\hline $\begin{array}{l}\text { Mass Communication } \\
\text { and Documentation } \\
\text { Architecture and Town }\end{array}$ & 41 & (2) & 59 & (6) & 69.49 \\
\hline Planning & 16 & (13) & $24-$ & (14) & 66.67 \\
\hline $\begin{array}{l}\text { Mathematics and } \\
\text { Computer Science } \\
\text { Commercial and }\end{array}$ & 18 & (12) & 29 & (13) & 62.07 \\
\hline Business Administration & 31 & (4) & 53 & (9) & 58.49 \\
\hline Fine and Applied Arts & 33 & (3) & 64 & (4) & 51.56 \\
\hline Law & 33 & (3) & 49 & (10) & 48.98 \\
\hline Natural Science & 20 & (11) & 41 & (11) & 48.78 \\
\hline $\begin{array}{l}\text { Social/Behavioural } \\
\text { Science }\end{array}$ & 28 & (6) & 59 & (6) & 47.46 \\
\hline $\begin{array}{l}\text { Humanities, Religion and } \\
\text { Theology }\end{array}$ & 29 & (5) & 62 & (5) & 46.77 \\
\hline $\begin{array}{l}\text { Agric., Forestry and Fishery } \\
\text { Medical Science and }\end{array}$ & 15 & (14) & 36 & (12) & 41.67 \\
\hline Health Related Fields & 27 & (7) & 73 & (3) & 36.99 \\
\hline Service Trades & 21 & (10) & 59 & (6) & 35.59 \\
\hline $\begin{array}{l}\text { Education Science and } \\
\text { Teacher Training }\end{array}$ & 25 & (8) & 74 & (2) & 33.78 \\
\hline
\end{tabular}

Note: Figures in parenthesis are ranks of tertiary fields of study as far as differences in female participation are concerned.

Source: $\quad$ Computed from UNESCO Statistical Year-Book, 1990.

Thus, to be able to make a remarkable progress concerning female enrolment in the sciences at the higher education level, deliberate efforts must be made to address the issue of female interests in some courses and lack of interest in others. To this end, many people have suggested a 


\section{Annals of The Social Science Council of Nigeria, No. 6, January-December 1994}

number of things that can enlist the interest of women in the specific disciplines. Some have suggested that the natural ability of women to influence decisions would be used to put into place necessary interventions in favour of greater women's access to prestigious and popular courses. Nevertheless, unless women in positions of authority are themselves interested in changing the gender gap in the study of science, the present increasing representation of women in formal education and decision-making in Africa may bear no fruit.

It is of interest that most African countries have deliberately formulated policies and programmes against gender discrimination, especially in the provision and distribution of education. While these equity policies have helped in countries such as Lesotho, Egypt, Mali, Kenya, Burkina Faso, Morocco and Tanzania, majority of the countries in Africa are yet to experience significant positive impact of such policies. One of the major reasons for not seeing the impact of policies against gender discrimination is connected with the attitude of the women themselves as most of them seem not to be interested in the sciences.

The increased interest of the international donors in gender issues is very supportive of bridging the gap between women and men in many areas of life. It is capable of stimulating political support for programmes geared towards equalizing participation between men and women in so many fields of studies. Although the trend now is to support African programmes and projects given the condition that gender issues will be addressed, most women are yet to be objective in finding solution to the problem of gender gap. Rather than look inward and correct women's internalized problems such as lack of interest in specific human endeavors, the tendency is to blame exogenous factors for the inability of women to meet up with their male counterpart.

Nevertheless, the initiatives of some Pan-African Organization (CODESRIA, 1991) in promoting research in Africa, particularly in the Social Sciences, is in the right direction to pin down the real problem and identify those factors which, if absent or changed, would accomplish the desired purpose. There are many of such factors apart from women's natural disinterestedness in a particular set of courses and professions, namely: parental attitudes regarding male supremacy and sex stereotype in career choice; early marriage; marital obligations to husbands and children; labour demand (female labour) which makes it uneconomical to release women to participate in higher education of long duration; unacceptability of western education or proprietorship which affects the willingness of some muslim women to participate in some forms of western education. Others are instability in African higher education systems which has the tendency of increasing the duration and costs of higher education and, hence, reducing the willingness of women to attend 
such institutions; narrow labour opportunities for women as it affects their perception of the economic benefits of higher education in general and science education in particular, the risk of pregnancy and bad behaviour in universities as they affect the willingness of parents to release women to enroll in higher education; lack of the right facilities and women teachers to take care of the special interests of women in higher education, etc.

A close look at these factors reveals that most of them have some underpinning effects on women's interest to study science in higher education. They either push up the private costs of higher education or reduce the private benefits to whether or not a particular higher education course should be pursued. The next section of this paper will focus on the strategies African countries can adopt to stimulate the interest of women in the sciences at the higher educational level in the continent.

\section{SUGGESTED STRATEGIES FOR AFRICA}

Looking at various factors which have, hitherto, been limiting female enrolment in science courses, three groups of strategies can be identified. These are expansion, costreducing and benefit-increasing strategies.

\section{Expansion Strategy}

This involves increased supply of institutions, as it was done in Britain in 1988, Egypt in 1981 and Yemen in 1987. Any country with unsatisfied or excess demand problem could use this expansion strategy. Countries can build new schools, extend higher institution places to more women, particularly in rural areas, renovate foisting buildings and establish vocational centres for women.

Expansion strategy has not been very successful in Africa, especially in bridging the gap between male and female attendance in higher education particularly in some science and technology courses. It will require a selective expansion in favour of women if we want the strategy to work moreover, it is one thing to provide the places in higher education, but another to get the women to fill them.

It will be useful to develop complementary programmes to address the issues of willingness, ability and readiness of girls and women to attend school or pursue the desired courses.

\section{Cost-reducing Strategies}

These are meant to overcome the problem of economic disability of some girls and women to participate in higher education. For the direct costs, 
the provision of scholarship for women has been effectively utilized in Bangladesh in 1982, Guatemala in 1987 and India and Nepal in the early 1980s, respectively. As far as the opportunity cost of higher education is concerned, two effective strategies have been tried in the past. Firstly, the provision of culturally appropriate facilities as in Mali, where provisions were made concerning community schools with pedagogic support (1989) and in Kenya and Pakistan where secularized curricula in Koranic schools and Mosques were provided, respectively, to attract women. Secondly, in places like Bangladesh and India, safety nets have been successfully built to provide alternative routes for women. For instance in India (1970), non-formal evening schools for out-of-school youths were provided and supported by both government and UNICEF.

Flexible school schedule, work study, distance education and sandwich programmes are good examples of strategies that can be used to reduce earnings foregone by women while in the university.

\section{Benefit-raising Strategies}

These are meant to raise the socio-economic benefits of higher education particularly to women. In most cases, emphasis is placed on raising women's earnings after higher education. As tried in Chile in 1968, Morocco in 1979, Tanzania in 1975 and Yemen in 1987, women vocational training can be provided and linked directly to employment and with strong recruitment. There should be a specially designed employment scheme to guarantee automatic employment of women scientists in various growth sectors of the economy. It is believed that incentives of this kind are capable of motivating some, of the women to enroll for the sciences in higher education. Since generalization can be dangerous in a continent of heterogeneous circumstances, this paper will go a step further to be more specific concerning what African countries should do with respect to increasing women's access to the sciences in higher education. Effort is therefore made in the next section to classify Africa into three main strategic cells within which similar strategies can be employed.

\section{COUNTRY-SPECIFIC WOMEN EDUCATION PROGRAMME FOR AFRICA}

Each African country has to study its situation critically since access programmes are bound to vary from one country to another. Countries differ in policies and programmes concerning women's access to higher education for four main reasons. Firstly, educational characteristics vary among countries. For instance, Table 3 shows that some African countries 
like Lesotho and Egypt performed significantly better than others such as Central African Republic, Chad and Mali. More so, the performance by field of study vary across the continent. It is, therefore, essential to avoid over-generalization in recommending gender specific access programmes in higher education in Africa.

Secondly, student's characteristics vary from one country to another. This is because what students consider as costs and benefits of education vary. For example, while women's enrolment ratios in higher education in 1990, were generally very low when compared with those of men in all African countries, in Lesotho, Swaziland, Mauritius and Botswana, there were no obvious gender gaps as far as gross enrolment in higher education is concerned.

Thirdly, the context of the economy also determine whether or not a particular access programme can be implemented in a country. Poor African countries may not be able to afford some costly interventions. It has been observed that, on the average, African countries can afford $\$ 0.60$ per child on school supplies, as against $\$ 200$ per child in developed countries (UNESCO/UNICEF, 1990). Moreover, the labour market situation will also determine the level of risk of unemployment after graduation. Since the labour market situation is likely to vary from one country to another, it will be advisable for each country to study its context before implementing programmes geared towards women employ-ability.

Fourthly, the objectives of education stressed by a country will equally determine the guidelines on women's access to higher education. While poor countries may be stressing educational objectives that will satisfy the basic manpower and educational needs of their people, the rich ones may be concerned with promoting equal educational opportunities. One country may see distance as the main barrier to female participation, while another may stress supply of schools and facilities. Definitely, the priority problems are bound to vary by country. Hence, the need for country-specific women education programmes.

Table 4 shows the classification of African countries according to the percentage of women in total science enrolment in higher education. Countries with very low women's science enrolment such as Togo, Chad, Central African Republic, Congo, Niger, Rwanda, Ethiopia, Tanzania and Mali should be the immediate targets of these strategies and, hence, they should vigorously pursue the goal of bridging gender gap.

However, both Mali and Tanzania have recognized the low science and technology enrolment as problems. For instance, Mali launched media campaigns in 1989 to advertize the value of education of girls (the gender-specific intervention may not have started yet). The project involved the provision of community schools with pedagogic support. Mali 
76 Annals of The Social Science. Council of Nigeria, No. 6, January-December 1994

Table 3:

Percentage of Females in Total Enrolment by Field of Study in African Higher Education

\begin{tabular}{|c|c|c|c|c|c|c|c|c|c|c|c|c|c|c|c|c|c|c|c|}
\hline \multicolumn{2}{|c|}{ Country } & \multirow[b]{2}{*}{07} & \multirow[b]{2}{*}{46} & & & & & & & & & & & & & & & & \\
\hline 1. & Algeria (1968) & & & 03 & 27 & 36 & 30 & 43 & $\sim$ & \multirow{2}{*}{$-\overline{13}$} & 43 & 21 & 38 & 21 & 26 & 29 & 02 & 31 & 32 \\
\hline 2 & Benri(1987) & 11 & 20 & - & 17 & 47 & 11 & 18 & - & & 12 & 09 & 17 & 08 & - & - & - & 04 & 21 \\
\hline 3. & Boswana(1980) & 48 & 38 & - & - & 39 & 43 & 69 & $\sim$ & - & 26 & 39 & - & - & - & - & - & - & \\
\hline 4. & BuWnaFaso(1986) & 15 & 37 & 17 & 31 & 26 & 26 & - & $\sim$ & - & 21 & 05 & - & - & - & - & - & 08 & - \\
\hline 5. & Butrd(1967) & 23 & 28 & - & 24 & 28 & 55 & 41 & - & - & 16 & 04 & 24 & 13 & 20 & 04 & - & 14 & 07 \\
\hline 6. & Cameroon (1980) & 14 & - & - & 23 & 16 & 19 & 05 & - & - & 15 & 04 & 21 & & & & & & 05 \\
\hline 7. & Certral Atari & & & & & & & & & & & & & & & & & & \\
\hline \multirow[b]{2}{*}{8.} & HepiWc(1968) & 02 & 06 & - & 12 & 03 & 15 & - & - & - & 06 & - & 29 & - & - & - & - & 02 & - \\
\hline & Chad (1987) & 02 & 10 & - & 10 & 10 & & & & & $\mathrm{AC}$ & & & & & & & & \\
\hline 9. & Congo (1987) & 15 & 11 & - & 31 & 11 & 35 & 17 & - & - & 06 & 06 & 21 & 10 & - & - & - & 13 & 05 \\
\hline 10 & Cote DTvoim (1987) & - & 30 & 17 & 07 & 33 & 45 & - & - & - & 11 & 03 & 32 & 04 & 03 & 02 & 05 & 07 & - \\
\hline 11. & Egypt (1987) & 46 & 47 & 47 & 20 & 42 & 30 & 56 & 79 & 79 & 40 & 27 & 41 & 13 & - & - & - & 32 & 36 \\
\hline 12 & Ethiopia (1988) & 17 & 22 & 09 & 12 & 16 & 34 & 32 & 35 & - & 09 & 17 & 13 & 07 & 08 & 05 & & 06 & - \\
\hline 13 & Carbon (1987) & 17 & 31 & - & 31 & 34 & 39 & 33 & - & - & 14 & 14 & 49 & 07 & 10 & - & 19 & 13 & - \\
\hline 14. & Ghara (1980) & 26 & 21 & 28 & 15 & 20 & 15 & 28 & 100 & - & 12 & - & 22 & 17 & 16 & - & - & 10 & - \\
\hline 15 & Ojnea(1968) & 17 & OS & - & 05 & 06 & - & - & - & - & 14 & 05 & 04 & - & - & - & 07 & 01 & - \\
\hline 16 & Kenya (1987) & 40 & - & 62 & 42 & 31 & 39 & 48 & 90 & - & 15 & 32 & 25 & 03 & 20 & 25 & - & 18 & 31 \\
\hline 17. & L8SO()TO(1967) & 73 & 65 & 89 & 44 & 48 & 83 & 80 & - & - & 31 & 64 & - & - & - & 12 & & 42 & - \\
\hline $\mathrm{m}$ & Uberia(1967) & 40 & 23 & 29 & 25 & 62 & 29 & 61 & - & - & 33 & 19 & 19 & 02 & 01 & 08 & - & 03 & 17 \\
\hline 19. & Madagasca(1968) & 40 & 64 & - & 47 & 39 & 40 & - & _ & - & 40 & 16 & 45 & $13^{\prime}$ & - & - & 18 & 35 & 16 \\
\hline 20. & Makjw(1967) & 33 & 11 & - & 04 & 14 & 17 & - & - & - & 14 & - & - & 75 & - & - & - & 13 & - \\
\hline 21. & Mai (1987) & 09 & - & - & 11 & 20 & & & & & & & 23 & 04 & - & & 26 & 10 & - \\
\hline & tinl i *!._'_/H(M7\ & jri & & & fi7 & $4 A$ & & & & & $1(5$ & & & & & & & & \\
\hline & Martana $\quad(\mathrm{iHo} / \mathrm{j}$ & $1 \mathrm{U}$ & & & Of & $(4$ & & & & & lo & & & & & & & & \\
\hline 23. & $23, \mathrm{Mau} \ll \operatorname{us}(1968)$ & 47 & - & - & 47 & 27 & 23 & & 100 & 25 & 45 & 35 & 10 & 06 & & 28 & & $19-$ & 20 \\
\hline 14. & Morocco (1987) & 28 & $\overline{4} 2$ & 10 & 27 & 31 & 51 & 37 & - & 38 & 28 & - & 33 & 12 & 17 & 15 & $\overline{11}$ & 22 & 37 \\
\hline 25 & Mozambique (1987) & 23 & - & - & 21 & $3 \mathrm{D}$ & - & - & - & - & 43 & 45 & 54 & 06 & 10 & - & - & 26 & - \\
\hline 26 & Nger(1968) & 20 & 23 & - & 15 & 16 & - & - & - & - & 08 & 02 & 22 & - & - & - & - & 05 & - \\
\hline 27. & Ngeria*(1989) & 47 & 35 & - & 25 & 24 & 23 & - & - & - & 27 & - & 24 & 9 & 14 & - & - & 24 & 37 \\
\hline 26 & Rwanda (1987) & 27 & 09 & - & 34 & 31 & 27 & - & 50 & - & 08 & 10 & 21 & - & - & - & - & 04 & - \\
\hline 291 & Senegal (1988) & 12 & 23 & - & 18 & - & - & 33 & - & 30 & 11 & - & 34 & - & - & - & - & 08 & 34 \\
\hline 30. & Somafa(1S87) & 20 & 20 & 42 & 23 & 15 & 31 & - & - & - & 11 & - & 24 & 02 & - & - & - & 15 & - \\
\hline 31. & Sudan (1987) & 45 & 50 & 24 & 39 & 39 & - & - & - & - & 41 & 24 & 44 & 14 & 25 & - & - & 35 & 17 \\
\hline 32 & Swazfend(1987) & - & 61 & - & 33 & - & 43 & - & 100 & 83 & 28 & & & & & & & 13 & - \\
\hline 33 & Tanzania (1987) & 19 & 20 & - & 19 & - & 16 & - & 33 & - & 09 & - & 14 & 05 & - & 06 & 28 & 11 & - \\
\hline 34. & Togo (1987) & 25 & 18 & - & 17 & - & 06 & - & - & 40 & 04 & - & 15 & 01 & 01 & - & - & 03 & - \\
\hline 35 & Tirisia(1988) & 31 & 46 & 57 & 37 & 34 & 44 & 64 & 55 & 49 & 33 & 26 & 53 & 12 & 45 & - & 23 & 19 & - \\
\hline 36 & Uganda (1987) & 19 & 32 & 45 & 31 & 23 & 0 & 24 & - & - & 16 & 09 & 22 & - & & - & & 18 & - \\
\hline
\end{tabular}

Note: " "-" represents data not available

* enrolment is defined as new entrants (sub-degrees, first degree and postgraduate) Source:

UNESCO Statistical Year Book, 1990 National Universities Commission

(NUQ, 1990 Annual Report for Data on Nigeria. 
Women's access to service programmes in higher education in Africa 77

wanted to build and renovate school building as part of the strategy to attract girls and women to school. Nevertheless, access projects directed towards participation of women in higher education are not common in countries.

Countries with between 10 and 30 per cent female science enrolment should not relent in their efforts, but explore more effective avenues of bridging the existing gender gap. Apart from Kenya (where secularized curricula in Koranic schools were established to attract more female students), Burkina Faso (where labour-saving machines were distributed by UNESCO to encourage non-formal education of women) and Morocco (where materials and extension services were developed to promote girls' education), none of the African countries under category B has deliberately adopted gender-specific interventions to raise female enrolment, particularly in higher education.

\section{Table 4:}

Classification of African Countries According to the Percentage of Women in Total Natural Science Enrolment in Higher Education.

$\begin{array}{lll}\begin{array}{l}\text { Category A } \\ \text { fewer than 10\%) }\end{array} & \begin{array}{l}\text { Category B } \\ (10 \%-30 \%)\end{array} & \begin{array}{l}\text { Category C } \\ \text { (more than 30\%) }\end{array} \\ \begin{array}{l}\text { Togo (04) } \\ \text { Chad (05) }\end{array} & \begin{array}{l}\text { Cote D'lvore (11) } \\ \text { Senegal (11) }\end{array} & \begin{array}{l}\text { Lesotho (31) } \\ \text { Liberia (33) }\end{array} \\ \text { Central African } & \text { Somalia (11) } & \text { Tunisia (33) } \\ \text { Republic (06) } & \text { Benin (12) } & \text { Egypt (40) } \\ \text { Congo (06 } & \text { Ghana (12) } & \text { Magadascar (4) } \\ \text { Niger (08) } & \text { Guinea (14) } & \text { Sudan (41) } \\ \text { Rwanda (08) } & \text { Malawi (14) } & \text { Algeria (43) } \\ \text { Ethiopia (09) } & \text { Gabon (14) } & \text { Mozambique (43) } \\ \text { Tanzania (09) } & \text { Mameroon (15) } & \\ \text { Mali (not certain) } & \text { Kenya (15) } & \\ & \text { Burundi (16) } & \\ & \text { Uganda (16) } & \\ & \text { Burkina Faso (21) } & \\ & \text { Botswana (26) } & \\ & \text { Nigeria (27) } & \\ & \text { Morocco (28) } & \\ & \text { Swaziland (28) } & \end{array}$

Note: Figures in parentheses are percentages of total enrolment of women. Source: Same as Table 3. 
78 Annals of The Social Science Council of Nigeria, No. 6, January-December 1994

Lesotho, Liberia, Tunisia, Egypt, Madagascar, Sudan, Algeria, Mozambique and Mauritius should consolidate their efforts and find ways of coping with relapses which may occur as a result of non-sustenance or inattention.

\section{CONCLUSION}

From all indications, there is a need to encourage gender-specific access policies and programmes in many African countries. Men and women should not be placed on the same pedestal as far as criteria for admission and other educational standards are concerned. Equality in costs of education, for instance, may allow discrimination against many poor African women, while equality in admission criteria may screen out some women in the areas of science and technology. In agreement with Kneller (1964), "in order to be fair to the disadvantaged we must treat them differently" through womenspecific educational policies and programmes.

There is a natural dichotomy between men and women with regard to interests in some courses and in certain professions. To be fair to the women, they must be made to enjoy preferences, at the interim, in recruiting graduates into key positions in the African society in general and in institutions of higher learning in particular. This preferential provision of employment will increase the financial benefits of education to women and reduce the risk of women's unemployment.

Many African women find it difficult to embrace higher education because of marital responsibilities. Any such interventions that will release them to take part in higher education will go a long way in bridging the existing gender gap in science and technology.

\section{REFERENCES}

Babalola, J. B. (1993): "Impact of Colonialism on Women's Access to Higher Education in Nigeria" (Forthcoming in UNESCO AFRICA)

Babalola,, J. B. (1993): "Differing Policies on Access to Higher Education in Africa" (mimeograph)

Bellew, R T. and E. M. King(1991): "Educating Women: Lessons from the Past." In E.M. King \& M. A Hill (eds), Women's Education in Developing Countries: Barriers, Benefits and Policy, PHREE/ 91/40, World Bank, pp. 251-285.

Codesria (1991): "Gendering Social Sciences." In Codesria Bulletin, Senegal: Codesria. 
Women's access to service programmes in higher education in Africa. 79

Hyde, KA.L. (1991): "Sub-Saharan Africa.", In E.M. King and MA Hill (eds), Women's Education in Developing Countries: Barriers, Benefits and Policy, PHREE/91/40, World Bank

Kneller, G. F. (1964): Introduction to Philosophy of Education. New York: John Willey\& Sons.

Knowles, A. S. (ed., 1977): "Access to Higher Education." In the International Encyclopedia o£ Higher Education. Vol. 24, pp. 83-90.

UNESCO (1991): "Special MINEDAF VI." In UNESCO AFRICA, No. 3.

UNESCO (1992): Higher Education in Africa: Trends and Challenges for the 21st Century. Dakar: UNESCO-Breda.

UNESCO-UNICEF (1990): Educate or Perish: Africa's Impasse and Prospects, Study Directed by Joseph Ki-Zerbo. Senegal: UNESCO-UNICEF. 